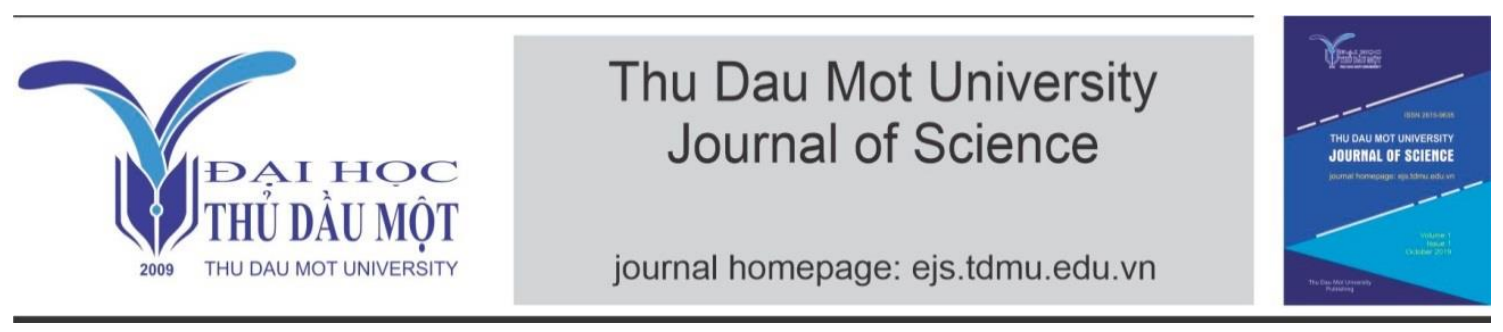

\title{
COVID - 19: a test for globalization
}

by Lê Thị Bích Ngọc (Thu Dau Mot University)

Article Info: $\quad$ Received 22 April 2021, Accepted 2 July 2021, Available online 15 Sep 2021

Corresponding author: ngocltb@tdmu.edu.vn

https://doi.org/10.37550/tdmu.EJS/2021.03.209

\begin{abstract}
In the last days of 2019, when the whole world was waiting for the moment to enter a new decade, a strange kind of unexplained pneumonia appeared in Wuhan city, China. From the little information as well as attention initially, this epidemic has turned into a pandemic worldwide. The quick-fire coronavirus spread and the response of different countries to it highlight immediate concerns about public health and have a significant impact on the evolving world order and the values that underpin it. This pandemic is unprecedented in its capacity to take advantage of modern globalization, allowing for massive disease spread at a surprising speed. It can say that COVID-19 is an additional blow to the vision and practices of the globalization process that is already under strain. Using the conceptual approach, the article, on the one hand, tried to analyze the challenges that globalization is facing because of COVID-19. On the other hand, the study want to affirm that globalization will still be an irreplaceable trend in the future.
\end{abstract}

Keywords: COVID-19, globalization, irreplaceable trend

\section{Introduction}

According to the World Health Organization (WHO), on 31st December 2019, its country office in China reported that pneumonia of unknown cause was detected in Wuhan (McKibbin \& Fernando, 2020). On 30th January 2020, WHO finally declared this epidemic as a global pandemic. And it is considered humanity's greatest challenge since the two World Wars. When writing these lines, the pandemic affects 192 countries and territories, with around 136,000,000 confirmed cases of COVID-19, more than 
2,900,000 deaths (WHO, 2021). However, the negative impact of the COVID-19 outbreak is not limited only to the loss of lives insofar as it has short and long-term socio-political-economic effects throughout the world.

The outbreak hones the understanding that with the free passages of people and goods among countries, globalization also facilitates the spread of disease. Under the influene of the COVID-19 pandemic, many countries have banned or imposed restrictions on personal, social and cultural interactions and international trade exchanges. The pandemic seems to be a significant blow to globalization's current form (Bremmer, 2020), which slows its speed. It even may create a new version of globalization that is more regulated (Hulton, 2020). Besides, globalization, with the worldwide flow of goods, people, money, information, technologies, and ideas at massive scale and speed, might also be responsible for allowing the speedy spread of the outbreak. For example, since the spread of the COVID-19 heavily relies on human-to-human- interactions, the movement of people internationally could be a dominant driver of its outbreak. Thus, COVID-19 is creating a reconsideration of the current globalization wave and whether it should be revived or remodelled. Remember, globalization has been heavily criticized prior to the pandemic (Buckley \& Hashai, 2020).

Therefore, this article's objective is to explore the significant impacts of the COVID-19 on all aspects of people's lives and analyses the link between globalization and the COVID-19 pandemic. Before that, we present a historical framework of the term "globalization". Then, we highlight what this pandemic reveals about globalization. Besides, by our arguments, we believe the crisis is also an opportunity to revive globalization. Specifically, the pandemic also determines the importance of international organizations, WHO, for instance. They are critical for dealing with public health challenges such as the Coronavirus epidemic. Without these enthusiastic organizations, things would be more demanding.

\section{Methodology}

Throughout human history, globalization and pandemics have been closely intertwined. In this article, we study the interplay between human interactions - motivated by an economically integrated world - and the prevalence and severity of pandemics.

In this research, the method of analysis is performed to collect data which are on prestigious web pages, in textbooks and relevant documents, Such data are managed and analyzed to prove the role of globalization in the process of Covid-19, revealing relevant ideas and insights.

\section{Research background}




\section{When did globalization start?}

Globalization has been one of the most discussed terms in contemporary social sciences for about 25 years. It is a highly variable term because there will be different perspectives when approached from many different angles.

In general, globalization can understand the process of increasing the interconnection and interdependence among individuals, organizations, nations, and peoples worldwide in all aspects of social life. In other words, referring to globalization refers to scale and speed because it creates a series of interconnected networks globally blurring traditional national boundaries. All things and phenomena happening in globalization can affect almost immediately different subjects on a worldwide scale.

Such globalization is not an entirely new phenomenon, but on the contrary, it started to appear long ago, right from medieval times, with Silk Road from East Asia to the Mediterranean for trading goods, merchandises, people and slaves. However, due to the underdeveloped production and transport forces, the exchange can only be done on a small scale.

By the fifteenth century, when the geographic discovery movements exploded along with the strong development of advances in science and technology (especially in the maritime field), which promoted the trade of countries across the continent. Besides, the emergence of (classical) capitalism and the Industrial Revolutions' success helped the production volume and production activities develop beyond national borders. The increasing association of actors in this period only stopped at internationalization because of political factors.

Only when the Cold War ends, especially the collapse of the Soviet Union in the 1990s, does globalization have more conditions to accelerate when the world no longer divided into blocks of economic-political opposition. Countries shifted to prioritize focusing on economic development, expanding exchanges and diversifying foreign economic relations, implementing open-door policies, actively participating in regional and international organizations. The remarkable growth of productive forces, the unprecedented growth of economic ties, and the fierce competition in all regions and worldwide are the most noticeable in this period.

Although globalization may have appeared for a long time, only in the past ten years, with the strong support of the achievements of the 4.0 industrial revolution, globalization has really created the big difference that occurred at an unprecedented speed and intensity.

Industrial Revolution 4.0 is built on the foundation of the digital revolution with the popularity of technologies such as connected things, artificial intelligence, cloud computing, etc. These changes are changing the way individuals, organizations, 
governments, and companies interact with each other and, at the same time, change the world. It can be said that, with ever-easier mobility, internet connectivity worldwide, the emergence of global problems, new trade agreements, and developing country economies. Quickly, it all combined to create an ever-tighter and more intricate interwoven system.

To conclude, in the age of globalization, "every resident of Earth is more or less involved in decisions made outside of their home country but doesn't affect on those decisions" (Guillochon, Bernard, 2011). Today's world is a "flat world" -precisely the term author Thomas L. Friedman in his famous work "The World is Flat" to describe the world.

That is also why the emergence and expansion of the COVID-19 could bring about immediate bad consequences.

\section{COVID-19 and the fragility of the globalization era}

Globalization increasingly shows that it is an inevitable development trend of the times. The views and attitudes towards Globalization are very different. While some countries embraced this trend enthusiastically, there are also many other countries that show reservations and attitudes that are hesitant, apprehensive, or even fiercely opposed. It must be admitted that, whether for or not to support this trend, countries today are discussing it, trying to make decisions that can take advantage of the advantages while minimizing the disadvantages from this trend.

COVID-19 takes place, showing how "fragile" the world of Globalization was. It should be known that, in history, humanity has faced many times, such as world-class pandemics. The pandemic world can be mentioned such as Justinian pandemic in 541, Plague (popular with the name "Black Death") in 1347, or most recently the Spanish flu pandemic in 1918, influenza A /2009 H1N1. All these pandemics have had an incredibly high number of people infected and fatal. However, only COVID-19 created unprecedented "shocks" in all aspects of such social life.

Globalization makes infectious diseases spread rapidly and promotes deep interdependence among actors, making them more vulnerable to sudden shocks. The ability to travel anywhere in the world in a short amount of time, carrying viruses with hand luggage, has allowed the epidemic to spread and flourish when they could have been eradicated in the past. Since the outbreak of COVID-19 until now, many research papers all admit that this pandemic has created an unprecedented crisis since the second world war, affecting all aspects of human life on a global scale.

\section{First of all, it has created a deep medical crisis}

Coronavirus is dangerous in that it secretly spreads in the community. Many infected, 
asymptomatic people still go out to do their daily routines. Inadvertently, they passed the virus on to others. With the rapid spread in the community and the fact that there is no medicine to treat this virus in medicine, countries' health systems are easily overloaded.

Due to lack of medical equipment and supplies, lack of hospital beds, medical staff, COVID-19 has "broken" the world-class medical system of a series of countries such as Italy, France, America, Japan, etc. This pandemic has forced doctors and doctors to go against "Hippocrates oath" by doctors to chose the person treating according to age and health condition, just like in wartime. Many hospitals in Italy, France, and China prioritize treating COVID-19 children because they have a better chance of recovering than the elderly in the lack of resources. Making these terrible decisions will become an obsession that affects medical staff's mental health for a long time. This medical crisis also showed that most countries had depended heavily on supplies from China and India. It is what makes countries more vulnerable when this supply is interrupted.

Moreover, in fragile and conflict-affected countries, acts of violence during the COVID19 have already deprived hundreds of medical services and severely hindered the response. Among others, the bombardment and destruction of a 400-bed facility in Libya (United Nations, 2020) further reduced health authorities' ability and aid agencies to prepare for a full-blown pandemic.

In short, attacks on health care directly impact the ability of health systems to deliver services to those most in need and take a heavy toll on the psychosocial health of patients, critical health care providers on the frontline, and their families. As those continue to be targeted by acts of violence during this public health emergency, health systems must - among other things - prepare for shortages of health care workers unwilling or unable to report to work due to unsafe environments or obstruction in their personal lives.

\section{Secondly, COVID -19 has impacted on global economy}

Globalization has created an international market, building up a global supply chain network. The world witnessed the division of labor taking place on a worldwide scale. Specialization create higher efficiency in turn leading to economic growth.

However, globalization also creates a complex system of interdependence. Parts of a product can be made in dozens of different countries. As production and trade become global, "countries also become more interdependent because no country can control all the goods and raw materials that their economies need. National economies are already dependent on an extensive global supply chain network" (Henry Farrell \& Abraham Newman, 2020). 
In this global supply chain, China emerged as a "big world factory" (Fleix Richter, 2020). China is now an essential part of the global industrial apparatus, accounting for about a quarter of global production. Most of the world's leading enterprises in all areas either place their factories in China or depend heavily on the supply of raw materials and materials from this country. Even commercial sales from this billion-population market also play a significant role in the survival of businesses. The COVID-19 that happened in China dealt a heavy blow to the Chinese economy and created an economic Domino effect that affected almost the entire rest of the world as one in the era of globalization.

It must be emphasized that, while the COVID-19 pandemic broke out, the global economy was slowing down due to the influence of several factors, such as the Sino-US trade war, the rise of trade protectionism, and the fear of a recurring arms race. So, when the pandemic emerged, it created resonance factors that pushed the global economy into crisis.

The blockade measures widely adopted by many governments have severely affected the supply side as many factories have to shut down and on the demand side as consumers have to stay at home. Besides the blockade, restriction on travel also reduces the ability to cooperate and coordinate internationally in response to a pandemic.

In early April 2020, many international organizations have analyzed, updated and assessed the impact of COVID-19 pandemic and built up world economic growth scenarios in 2020 (Table 1). The World Bank's recent forecast present the global output decline by $5.2 \%$ in 2020, falling between the WTO's optimistic and pessimistic range (WTO, 2020). Other international organizations' GDP forecasts for 2020 are also increasingly negative, even as their trade projections stay roughly in line with the WTO's optimistic scenario. These estimates imply a less negative trade response to declining GDP growth than was observed during the global financial crisis of 20082009.

World trade fell sharply in the first half of the year, as the COVID-19 pandemic upended the global economy. However, rapid government responses helped temper the contraction, and WTO economists now believe that while trade volumes suffer a steep decline in 2020, they are unlikely to reach the worst-case scenario projected in April.

COVID-19 also substantially impact on the global labor market. According to the latest International Labor Organization (ILO) report published on April 7, 2020, the pandemic has affected $80 \%$ of working-age people, about 1.25 billion unemployed or wage decreased people worldwide. More seriously, this epidemic has left 198 million workers unemployed. In comparison to other places, the Asia-Pacific region is the most seriously affected with about 125 million unemployed people, while the number of unemployed 
Europeans is 20 million (ILO, 2020).

TABLE1. Summary of recent forecasts for world GDP and Trade (WTO, 2020)

\begin{tabular}{lcccccc}
\hline & \multicolumn{2}{c}{$\begin{array}{c}\text { Real GDP } \\
(\% \text { change })\end{array}$} & \multicolumn{2}{c}{$\begin{array}{c}\text { Trade volume } \\
(\% \text { change })\end{array}$} & \multicolumn{2}{c}{$\begin{array}{c}\text { Elasticity } \\
\text { (ratio) }\end{array}$} \\
& 2020 & 2021 & 2020 & 2021 & 2020 & 2021 \\
\hline WTO Trade forecast (April 2020) & & & & & & \\
- optimistic scenario & -2.5 & 7.4 & -12.9 & 21.3 & 5.3 & 2.9 \\
- pessimistic scenario & -8.8 & 5.9 & -31.9 & 24.0 & 3.6 & 4.1 \\
IMF World Economic Outlook (April 2020) & -3.0 & 5.8 & -11.0 & 8.4 & 3.6 & 1.4 \\
World Bank Global Economic Prospects (May 2020) & -5.2 & 4.2 & -13.4 & 5.3 & 2.6 & 1.3 \\
OECD Economic Outlook (June 2020) & & & & & & \\
- single hit scenario & -6.0 & 5.2 & -9.5 & 6.0 & 1.6 & 1.1 \\
- double hit scenario & -7.6 & 2.8 & -11.4 & 2.5 & 1.5 & 0.9 \\
Memo items: & & & & & & \\
IMF GDP at market exchange rates & -4.2 & 5.4 & -11.0 & 8.4 & 2.6 & 1.6 \\
World Bank GDP at purchasing power parity & -4.1 & 4.3 & -13.4 & 5.3 & 3.3 & 1.2 \\
\hline
\end{tabular}

All of the above figures are temporary as the epidemic continues to be complicated overall, with the number of infections and deaths increasing each day. Although governments are trying to take drastic measures to prevent the outbreak, the world economy's picture will be much more gloomy if these measures do not work.

With the current impacts of the COVID-19 pandemic on the world economy, there are opinions that this pandemic can entirely create a new world economic crisis with a degree of loss. More harmful than the world financial crises that have taken place in history, such as the first world economic crisis in 1857-1859, the second world economic crisis of 1929-1939, and the financial crisis, public debt in 2008/2009.

However, compared with the world economic crisis mentioned above, the current pandemic expresses four fundamental differences.

First, all economies in the world do not accept the crisis caused by COVID-19 and certainly, they try the best to escape from the problem. Second, although we still talk much about imbalances in the global supply chain, In general, this imbalance comes from both the supply and the demand side, not being significantly imbalanced compared to before. Third, the cause of economic slowdown is not systemic or structural but from the administrative measures to deal with pandemics such as blockade, social isolation or isolation, blockade of national borders. Fourthly, globalization, trade liberalization, and international integration are much higher than before.

\section{Thirdly, it has impacted on global politics}

While the pandemic will influence ways of living and ways of dealing with public health and global economic development, it will underline governments' vital role in everyday life. 
Many countries have been strongly criticized for their delayed and inconsistent response to the COVID-19, such as the US, UK, France, Italy, Brazil, Japan, etc. It will be a source of political turmoil within these countries even when the epidemic's effects are mitigated. Countries have gradually transformed the COVID-19 from a purely medical issue to an unforeseen political-diplomatic tension through policies to prevent the outbreak.

On a global political level, the pandemic's impact is subject to the great powers and, in particular, the United States' response to how the virus outbreak will affect its economy. The US has already set the tone by spinning the pandemic from being invisible to a visible enemy, singling China out as its source to appropriate and mandate a response. Based on this approach, the virus's main impact on global politics is that it will widen the rift between the US and China. The competition and mutual restraint between these two countries is always a problem that makes the world "fidgety". While the relationship between the two countries has just shown signs of postponement with the signing of the initial agreement in 2020, after more than two years of tit-for-tat in the intense trade war, this pandemic has shattered this initiation of normalization.

Both the US and China have used this pandemic to point out propaganda against the enemy. In many public forums, US President D. Trump has criticized China for hiding the disease, lack of transparency in officially published numbers, costing the whole world. Mr. D. Trump did not hesitate to name the pandemic "Chinese virus repeatedly" (Whitehouse, 2020). Even the Washington Post reporter Jabin Botsford took a photo showing President D. Trump's announcement of COVID-19 that the word "Corona" was crossed out with a pen and changed to "Chinese" (Jabin Botsford, 2020). This reaction of the US President in response to China after the statement of the country's foreign official Zhao Lijian (Lijian Zhao) said on his personal Twitter with the comment, "The US military may have carried the Coronavirus (causing COVID-19) to Wuhan" (Ben Westcott \& Steven Jiang, 2020).

The two countries confront each other in the information field as they continually seek to assign responsibility to each other for the virus's origin. The height of the media war was the expulsion of each other's journalists by China and the United States. Even the US President announced a suspension of funding WHO because he said that this organization has not fulfilled its responsibilities and accused WHO of bias and covering up China in the world.

Like the US-China, the Northeast Asia region is also witnessing a tense diplomatic atmosphere when Japan - South Korea also constantly retaliate against introducing isolationist policies against the public. If the epidemic continues to develop complicatedly, the political-diplomatic relations between countries and partners in the 
world will be significantly affected. Preventing people from the epidemic zone or citizens of the countries affected by the disease can be seen as an effective short-term policy in preventing the entry and spread of the virus but at the same time can become a "big story" between nations, peoples; between regions and continents.

\section{Finally, COVID - 19 has impacted on society}

COVID-19 has affected all walks of life in society, especially the community's vulnerable objects such as the poor, the elderly, the disabled, women, and children. Disease prevention strategies such as blockade, social isolation, or remote work have deepened inequality in society. Most people in the disadvantaged groups in the society mentioned above have little or no ability to work remotely. Due to the loss of income or decrease in revenue, while all living expenses are still payable, many families' financial capacity becomes more and more tight, leading to poor people.

Also, a series of bankruptcies in each country and globally due to COVID-19 have brought about many social consequences, such as reducing social aggregate demand and a sudden increase in unemployed people. From there, they are putting intense pressure on the work of ensuring security, income, and employment on both national and international scales. In that context, many countries have launched relief packages up to billions, even thousands of billions of dollars, to help businesses and workers overcome difficulties, significantly to help the underprivileged that are not being left behind. These bailout packages, up to now, have been identified as "unprecedented."

COVID-19 created an unprecedented social experiment: social distancing (maintaining a safe physical distance between individuals). People are required to stay at home; avoid gathering, exchanging in crowded places. All activities such as going to work, school, watching movies, dating, or even funerals are conducted online. People in the epidemic context are less likely to communicate in a face-to-face fashion, and they switch to interacting in a virtual world. Being active online is probably one of the most talkedabout phrases these days. It is possible that after the epidemic is over, some online activities will remain even more common than before the pandemic. However, the internet has existed for more than three decades, so translate COVID-19 is not the cause of these changes but the agent that accelerated them.

During the past months, the world has witnessed many large-scale protests in Germany, the US, and Brazil against the government's social stretch measures.

Another unforgettable substantial impact is that COVID-19 promoted racism. While the world struggles to cope with the epidemic, Asians have to bear additional fear of stigmatization in the US, Canada, UK, Australia, and several other countries. As people increasingly feel panicked and stuck at the powerful onslaught of COVID-19, they turn to find ways to vent their anger on those allegedly responsible for the epidemic, that is, 
the entire population of Asian origin. Many of the heartbreaking incidents in the West have been reported by the media, suggesting that they are facing increasing racism in the form of physical and mental attacks.

Besides, since this is an infectious disease, the likelihood of spreading it to others is very high, causing double effects for both the patient and the person who "thinks he might have the disease." For patients, they suffer stigma, avoidance, and fear from the community, making them not only a mere "patient" but also a "criminal" of society. As for those who have been in contact with the patient, they have panic psychology about their ability to be infected. All these things cause a state of psychosocial crisis.

\section{Results}

As mentioned above, COVID-19, on the one hand, has created an unprecedented crisis since the second world war. In my opinion, this difference compared to the problems recorded in history is due to the following principal reasons:

First, this is the global crisis. According to official statistics from reputable organizations globally, such as WHO, IMF, and Johns Hopkins University, all countries and fields are swept up, with blockade measures and inter-insolation concerned half of humanity.

Second, the fact that an economy suddenly stops due to a shutdown of production and demand is very different from a financial crisis to a wartime economy to save defense resources.

Third, this is a complex crisis in which three concerns are intertwined. The health crisis, with predictive models showing that the death toll will surely increase rapidly if there is no timely response from the public health sector-economic crisis, with a decline in global economic activity in 2020. And financial crisis with a collapse of markets, with the risk of bankruptcy and chain layoffs.

Fourth, the epidemic forces governments to change their policy priorities, force multilateral institutions to change agendas, and force people everywhere to change their minds and lifestyles.

Fifth, epidemics highlight the state's role and contribute to changing the relationship between the state and its people and national and international institutions.

Sixth, in response to this crisis, governments and central banks worldwide have enacted sweeping and sizable stimulus measures to counteract the disruption caused by the coronavirus and provide relief to those suffering from the pandemic. The scale and speed of the financial assistance measures in place are unprecedented, with a total amount of up to a billion dollars, credit, collateral from countries, Central Bank to 
protect businesses and families (IMF, 2021) On the other hand, COVID-19 has changed the nature of globalization. There's no doubt that State involvement in economic activity has increased noticeably. State support has morphed into State direction as businesses are ordered to produce critical products (ventilators, personal protective equipment), reconsider production locations, and increase supply resilience. These policies, designed to improve national security, are affecting globalization.

In other words, this pandemic has changed the global value chain. Over the past four decades, much manufacturing production worldwide has been organized in what has become known as global value chains (GVCs). Raw materials and intermediate goods are shipped worldwide multiple times and then assembled in yet another location. The final output is re-exported to final consumers located in both developed and developing markets. For many goods, China is at the heart of such GVCs - for example, as a primary producer of high-value products and components, as a significant customer of global commodities and industrial products, and as a substantial consumer marketplace. China is also producing many intermediate inputs and is responsible for processing and assembly operations. Foxconn, an electronics contract manufacturer, is a well-known example.

The fact that the coronavirus broke out in China is of particular significance. The rising Eastern power plays a critical role in the global economy, among other things, as the production hub of most consumed goods. We hailed this global production chain and the cheap goods it provided.

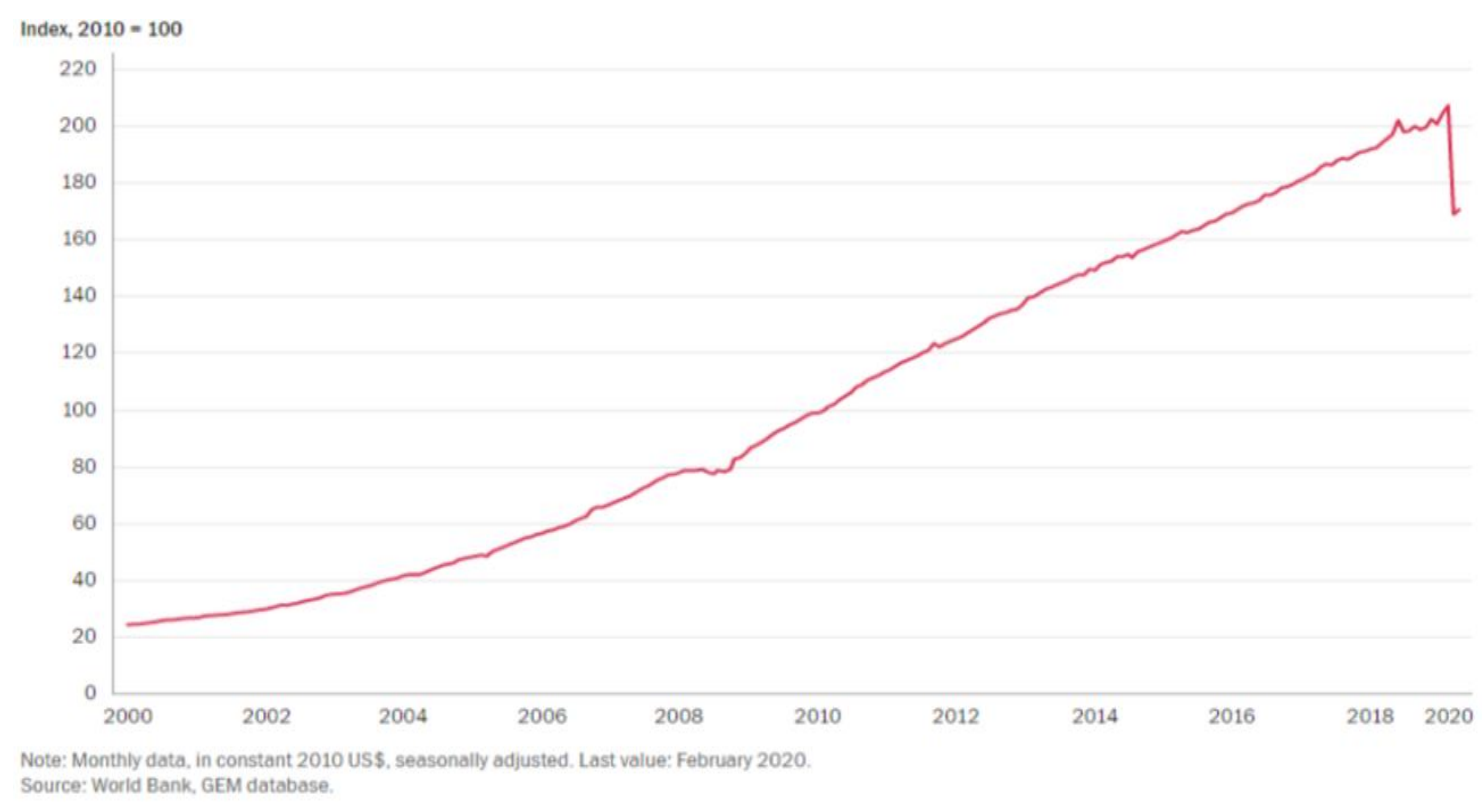

Figure 1. Industrial production in China (Adnan Seric, Holger Görg, Saskia Mösle, and Michael Windisch, 2020) 


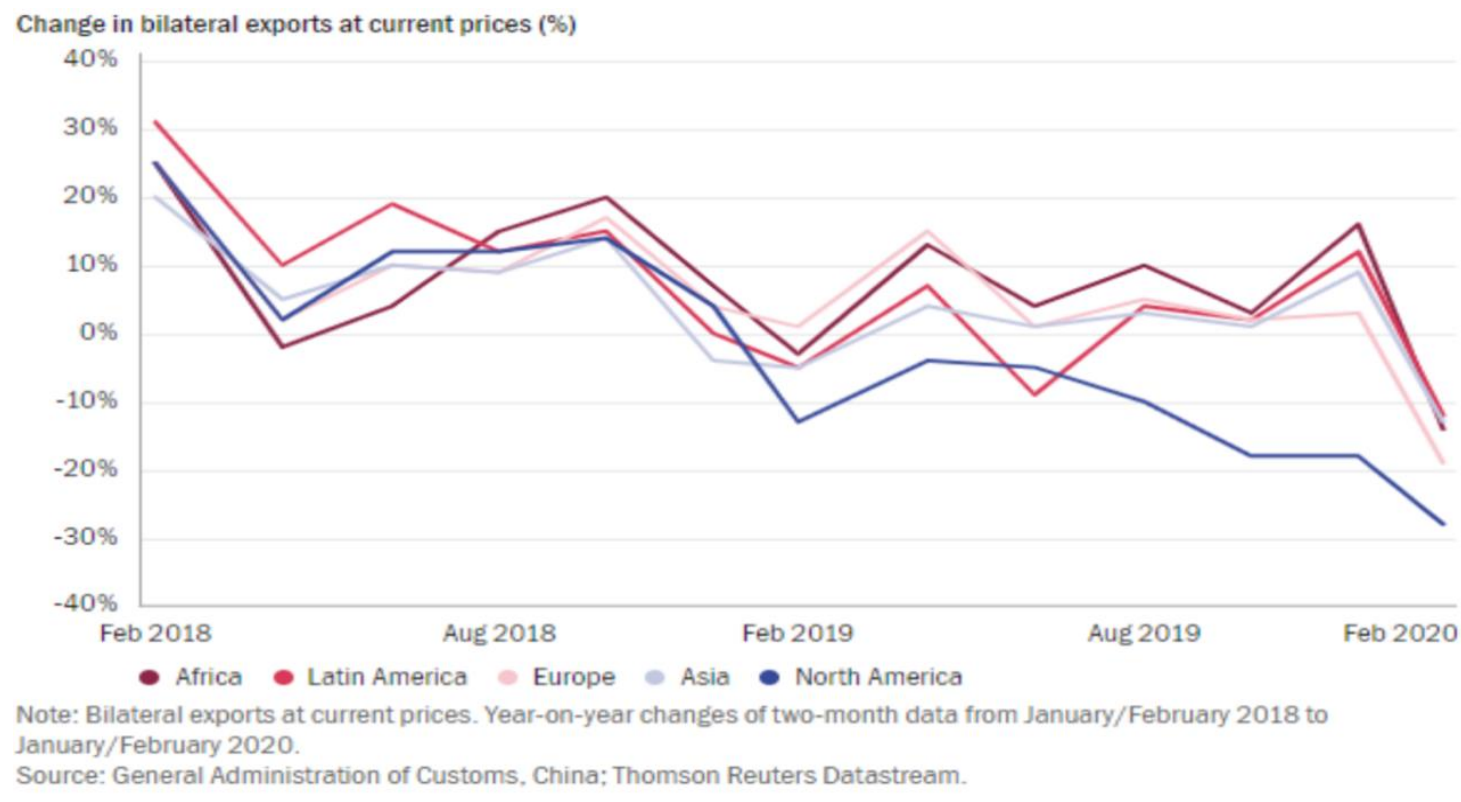

Figure 2. Chinese exports to the rest of the world (Adnan Seric, Holger Görg, Saskia Mösle, and Michael Windisch, 2020)

Many countries will presumably try to bring back home some of their essential production elements. Exports from China have declined to all regions across the world. This decline has been severe globally, where trade was already in the fall for more than a year due to the ongoing trade disputes between the US and China. The US under President Donald Trump was trying to do so anyway, albeit for different reasons. The weakened Chinese economic activity is expected to undermine the global economy and thereby further erode the achievements of globalization.

Moreover, COVID-19 is a test for global political status. The pandemic on global geostrategic affairs depends on the response from the great powers and the US in particular. It is also important to mention that those same political factors that preceded the pandemic are likely to be the same factors that determine its future impact. The rationale behind this assumption is that the outbreak wasn't as sudden an event as the 9/11 attacks, nor as grave in terms of consequences as the outbreak of the Second World War.

Although COVID-19 created a US-Sino competition, this article argues that the pandemic will not significantly change global politics. It will not change the nature of geo-strategic rivalries and the current balance of power. In the short term, the pandemic will not have as much impact as 9/11, and it will not create a new international order.

In my view, the crisis is likely to challenge the whole world order, with the expected rising tensions between China and the USA, the democratic versus autocratic regimes and their ability to handle the crisis, etc. 
China, a significant superpower in politics and world trade, where the virus first emerged and spread, faced and is poised to face diverse challenges to its economy and international affairs due to the losses and tensions born from COVID-19. The USA has also been facing an embarrassing situation on the national and international fronts. The handling of the pandemic has created a lot of mistrust and skepticism in the capabilities of the current administration in handling the crisis. Having just survived a protracted Brexit, the European Union witnessed embarrassing inter-state divisions about COVID19 combat, besides the reported disagreements and mutual appropriation of medical aid among member states.

Besides, COVID-19 is also an opportunity to revive globalization. First, the crisis is a reminder of our underlining unity as humans. Beyond divisions, wars, and hatred, the problem shows that different people share somewhat similar anxieties. Second, international cooperation is crucial. A coordinated, cross-border global effort to monitor and treat the disease and speedily develop and disseminate a vaccine across national borders will end the epidemic.

In both the Global North and the South, governments encountered hard decisions as to whether they are obliged to support the individuals and social groups negatively influenced by the pandemic. Some countries took action early, supporting those who lost their jobs in the pandemic and offering help to the vulnerable sections in society and the economy. Other governments shared responsibilities with the private sector and NGOs. In contrast, the third type of government transferred the entire burden of loss and vulnerability to the threatened groups through a public policy of silence and negligence.

\section{Discussion}

\section{The globalization is not the end in the long-term secenario.}

COVID-19 has made the world we live in have specific changes. It is also seen as a test drug for global cohesion, as people are increasingly vulnerable than ever. Many people have made predictions about the viability of globalization in the future, expressed clearly in two points of view: globalization will end or will continue to be the mainstream.

Even before the pandemic, this globalization revision emerged as the open trading system, which dominated the world economy for decades - gradually shrank by a strong resurgence and nationalism. The appearance of the COVID-19 has made the trend of globalization reconsider strong. Among them, many are that globalization will end. For example, the article by scholar John Gray (2020), the British political philosopher, said that "Era of peak globalization is over". Scholars Philippe Legrain (2020), published in the journal Foreign policy, said that "Coronavirus is killing globalization". 
However, I am inclined to the other view that globalization will not end because, like it or not, it is still the inevitable development trend of the era. The continued expansion of cross-border freedom of movement, circulation of goods, capital, currency, and information will create many new opportunities and prosperity. Anything or phenomenon has two sides: positive and negative. Looking at the history of human development, we can see that, since the Europeans of the 15th century pioneered the search for new communication methods, connecting the world, humanity has had how astonishing growth is.

The prospect of all countries bringing the whole production cycle back to internal is very far away because the problem of profitability in labor costs, local raw materials, markets will be obstacles pass. For decades, companies have worked relentlessly to reduce unnecessary periods and thereby achieve unprecedented high net worth. Globalization will create a world playing field, allowing manufacturers to build flexible supply chains by replacing one supplier with another, if necessary. Specialization will make it more efficient, and more efficient will increase profits and grow more.

During the COVID-19 crisis, global coordination still took place in the international medical and scientific community. Countries were willing to share their viral experiences to create test methods and prompt treatment quickly. It suggests that there is a basis to rely on common knowledge resources to deal with disease outbreaks in the future tense. Moreover, the emergence of global problems such as environmental pollution, poverty, inequality, climate change, nuclear weapons, criminal activities, etc., requires continued integration of the collective effort of the whole of humanity.

It can say that this pandemic is just a temporary "barrier" to the world. As soon as the pandemic ends, the movement of goods, services, capital, information, transportation, tourism, labor, etc., will gradually recover, but at a relatively slow rate due to all countries. to give priority to domestic demand stimulus first. Then, production chains will be adjusted in the direction of reducing production facilities from the "big world factories," which are China, to return home or gradually move to other potential regions such as Southeast Asia and India, avoiding dependence on a single supply, in case the same natural disasters or catastrophes occur.

COVID-19 made countries aware of the importance of investing more in the global and national health systems. Furthermore, it requires, even more bilateral and multilateral cooperation. Therefore, the current crisis will not end globalization and multilateralism. The withdrawal of countries will only make the international response to the global problem less effective, and they may suffer more severe consequences.

This pandemic has made the National Government clearly show its role and function. A race is underway to save lives, stabilize society, and maintain economic performance 
globally. Each country has its plan to handle the crisis that best suits them. Governments and central banks are pursuing unprecedented measures to reduce the global slowdown. COVID-19 is a sudden disaster for every country by exploiting globalization more thoughtfully; instead of blaming it for turning its back on it, each country will notice a substantial boost in resilience.

It is simply amazing how quickly the world has adapted to a new way of being. To a large extent, societies have maintained everyday life because goods have been delivered to our doorstep. We've kept in touch with friends, family, and work through digital connections.

Thanks to global collaboration, we're getting closer to finding effective treatments and vaccines for this virus. Adjustable supply chains and access to the worldwide market are helping us soften the economic impact.

The benefits of a connected world are visible everywhere. We've witnessed massive growth in cross-border e-commerce. Many companies with a global reach have found themselves in a much better position during this crisis than those with a purely national or regional focus.

Technology enables us to mobilize the planet's resources and bring together human ingenuity to fight this and future crises. That's why I believe the isolationist tendencies witnessed during this pandemic (whilst unavoidable, some would say) will be transitory. The way globalization works are changing, but it is far from disappearing.

In brief, this pandemic is not proof that globalization has failed, nor is it a sign that the end of globalization is necessary. After this disaster, we can see how vulnerable we are. Still, it is undeniable that globalization will continue to be the mainstream trend in the future with the more incredible benefits it brings.

\section{Conclusion}

The COVID-19 is shaping up to be an enormous stress test for globalization. As critical supply chains break down and nations hoard medical supplies and rush to limit travel, the crisis is forcing a significant reevaluation of the interconnected global economy. Not only has globalization allowed for the rapid spread of contagious disease, but it has fostered deep interdependence between firms and nations that make them more vulnerable to unexpected shocks. Now, firms and governments alike are discovering just how vulnerable they are.

However, the lesson of the new coronavirus is not the failure of globalization, despite its fragility, because its benifits must be really recognized. For decades, individual firms' relentless efforts to eliminate redundancy generated unprecedented wealth. But these 
efforts also reduced the number of unused resources-what economists refer to as "slack" - in the global economy as a whole. In regular times, firms often see slack as a measure of idle or even of squandered productive capacity, but too little slack makes the broader system brittle in times of crisis, eliminating critical fail-safes.

Lack of fail-safe manufacturing alternatives can cause supply chains to break down, as they have in some medical and health-related sectors due to the new coronavirus. Producers of vital medical supplies have been overwhelmed by a surge in global demand, pitting countries against one another in a competition for resources. The outcome has been a shift in power dynamics among major world economies, with those that are well prepared to overcome the pandemic either for accumulating resources or assisting the other and expanding their influence on the global stage as a result.

\section{References}

Adnan Seric, Holger Görg, Saskia Mösle and Michael Windisch. (2020). How the pandamic disrupt global value chains. Industrial Analytics Platform. Vienna: United Nations Industrial Development Organization (UNIDO).

Ahani, Ali, and Mehrbakhsh Nilashi. (2020). Coronavirus outbreak and its impacts on global economy: The role of social network sites. Journal of Soft Computing and Decision Support Systems, vol. 7, 19-22

Angel Alcalde and Jose M. Escribano. (2020). Will Covid 19 End Globalisation. The University of Melbourne, 16 May 2020, https://pursuit.unimelb.edu.au/articles/will-covid-19-endglobalisation

Ben Westcott and Steven Jiang. (2020). Chinese diplomat promotes conspiracy theory that US military brought coronavirus to Wuhan. Cable News Network (CNN), March 14,

Bilahari Kausikan. (2020). Speculations on Southeast Asia After COVID - 19, Asean Focus - A Quartely publication providing concise analyses and perspectives on Asean matters. The Istitute of Southeast Asia Studies, Issue 1.2020 : 1 - 4, ISSN: 2424-8045

Bremmer, Ian. (2020). Why COVID-19 May Be a Major Blow to Globalization. Time, March 5. Available online: https://time.com/5796707/coronavirus-global-economy/

Buckley, P. J., and N. Hashai. (2020). Scepticism Towards Globalisation and the Emergence of a New Global System. Global Strategy Journal, 10(1), 94-122.

Frederic Jenny. (2020). Economic Resilience, Globalization and Market Governance: Facing the COVID - 19 Test. Social Science Research Netwwork (SSRN), March 28, https://papers.ssrn.com/sol3/papers.cfm?abstract_id=3563076

Guillochon, Bernard, Ngân Điệp, Thu Trang (translate). (2011). Toàn cầu hoá - Duy nhất một hành tinh, nhiều dự án khác nhau. HCMC: Tre Publishing House.

Henry Farrell and Abraham Newman. (2020). Will the Coronavirus End Globalization as We Know It?. Foreign Affairs, March 16, https://apps.who.int/iris/handle/10665/68726 https://bom.to/gJKIvf 
https://edition.cnn.com/2020/03/13/asia/china-coronavirus-us-lijian-zhao-intlhnk/index.html https://foreignpolicy.com/2020/04/17/globalization-trade-war-after-coronaviruspandemicl https://iap.unido.org/articles/how-pandemic-disrupts-global-value-chains\#fn-154-1 https://stratnewsglobal.com/rethinking-globalisation-covid-and-the-international-order/ https://www.foreignaffairs.com/articles/2020-03-16/will-coronavirus-end-globalizationwe-know-it https://www.foreignaffairs.com/articles/china/2020-03-18/coronavirus-could-reshapeglobal-order https://www.ilo.org/wcmsp5/groups/public/@dgreports/@dcomm/documents/briefingnot e/wcms_740877.pdf

https://www.iseas.edu.sg/wp-content/uploads/2020/02/ASEANFocus-March-2020.pdf

https://www.theguardian.com/commentisfree/2020/mar/08/the-coronavirus-outbreak-shows-usthat-no-one-can-take-on-this-enemy-alone (accessed on 4 March 2021)

https://www.un.org/sg/en/content/sg/statement/2020-04-07/statement-attributable-thespokesman-for-the-secretary-general-libya https://www.whitehouse.gov/briefings-statements/remarks-president-trump-pressbriefing/ https://www.wto.org/english/news_e/pres20_e/pr858_e.htm

Hutton, Will. (2020). Coronavirus Won't End Globalisation, but Change It hugely for the Better. The Guardian, March 8. Available online:

International Labour Organization. (2021). ILO Monitor: Covid-19 and the the world of work. Second edition. Updated estimates and analysis,

International Monetary Fund Communication Department. (2021). COVID-19 Financial Assistance and Debt Service Relief. Last Updated April 19, https://www.imf.org/en/Topics/imf-and-covid19/COVID-Lending-Tracker

Jabin Botsford. (2020). Photo shows "corona" crossed out and replaced with "Chinese" in Trump's briefing notes. Cable News Network (CNN), March 19, https://edition.cnn.com/world/live-news/coronavirus-outbreak-03-19-20-intlhnk/h_21c623966aa148dbeed242de4e94943e

John Gray. (2020). Why this crisis is the turning point in history, Newstatement, 1 April 2020, https://www.newstatesman.com/international/2020/04/why-crisis-turning-point-history

Kano, L. (2018). Global Value Chain Governance: A Relational Perspective. Journal of International Business Studies 49(6), 684-705.

Kurt M.Campbell and Rush Doshi. (2020). The Coronavirus Could Reshape Global Order China is Maneuvering for International Leadership as the United States Falters. The Foreign Affairs, March 18,

McKibbin, Warwick, and Roshen Fernando. (2020). The Global Macroeconomic Impacts of COVID-19: Seven Scenarios. CAMA Working, Paper No. 19/2020. Cambridge: MIT Press.

Mohamed Buheji and Dunya Ahmed. (2020). Foresight of Coronavirus (COVID-19) Opportunities for a Better World. American Journal of Economics, 10(2), 97-108 
https://bom.to/dY1Qxg

Naushad Khan and Mahnoor Naushad. (2020). Effects of Corona Viruss on the World Community. Social Science Research Netwwork (SSRN), Febuary 4,

Philippe Legrain. (2020). Coronavirus is killing globalization as We know it. Foreign Policy, March 12, https://foreignpolicy.com/2020/03/12/coronavirus-killing-globalizationnationalism-protectionism-trump/

Richard Fontaine. (2020). Globalization Will Look Very Different After the Coronavirus Pandemic. Foreign Policy, April 17,

Saker, Lance, Kelley Lee, Barbara Cannito, Anna Gilmore, and Diarmid H. Campbell-Lendrum. (2004). Globalization and Infectious Diseases: A Review of the Linkages. Geneva: World Health Organization, Available online:

The Johns Hopkins Coronavirus COVID-19 Global Cases site

United Nations (2020) Statement attributable to the Spokesman for the Secretary-General on Libya [Press statement]. Available at:

Vijay Gokhale. (2020). Rethingking Globalization: Covid and the International Order. StratNews Global, April 8,

Whitehouse. (2020). Remarks by President Trump in Press Briefing. Healthcare, Issued on April 14 ,

Whitehouse. (2020). Remarks by President Trump, Vice President Pence, and Members of the Coronavirus Task Force in Press Briefing. Healthcare, Issued on: March 20, 2020 https://www.whitehouse.gov/briefings-statements/remarks-president-trump-vicepresident-pence-members-c-oronavirus-task-force-press-briefing/

World Trade Organization. (2020). Trade Statistics And Outlook-Trade falls steeply in the first haft of 2020. WTO news. 2020 Press release.

Yong, E. (2020). How the Pandemic Will End. The Atlantic, March 25, https://www.theatlantic.com/health/archive/2020/03/how-will-coronavirus-end/608719/ 